\title{
Paketleme Makinesinde Selofan Kaynak Yapma Mekanizmasının Pnömatik Kontrolü
}

\author{
Metin GUNER ${ }^{1} \quad$ Gökhan DUMAN²
}

Geliş Tarihi : 26.11.2000

\begin{abstract}
Özet: Bu çalıșmada bir yatay paketleme makinesinin termoplastik filmin şekillendiği bölümlerin, pnömatik ekipmanlar ve prensipleri kuilanılarak yeniden düzenlenmesi yer aimaktadır. Çalışma sonucunda mekanik güç aktarım sisteminin kullanım zorluklarının pnömatík sistem ekipmanları kullanılarak giderilmesi amaçlanmıştır. Pnömatik sistemin makineye adaptasyonu için PLC programı destekli elektropnömatik ekipmanlar kullanıımıştı. Kaynatma çeneleri, makas, lleticiler, tutucular, vakum elemanları ve üfleme bölümlerinde silindirler, hassas algılayıcı sensörler, yön kontrol valifleri ve basınç kontrol valleri kullanilmiștir.
\end{abstract}

Anahtar Kelimeler: Isıl kaynak, termoplastik film, paketleme makinesi, selofan kaynak yapma mekanizmas

\section{Pneumatic Control of Cellephone Welding Mechanism in Sachet Pack Machine}

\begin{abstract}
In this study, the reorganisation of horizontal sachet pack machine's thermoplastic film shaping parts are studied by using pneumatic system principles and equipments. It is aimed to prevent the usage difficulties of mechanical power transmission system with pneumatic system equipment at the end of the study. In order to adapt pneumatic system for the machine, electropneumatic equipment supported by PLC program are used. Cylinders, sensitive sensors, directional valves, and pressure control valyes are used on the sealing tools, cutters, carriers, grippers, vacuum tools, and blower.
\end{abstract}

Key Words: Thermic sealing, thermoplastic film, sachet pack machine, cellephone welding mechanism

\section{Giriş}

Kontrol edilebilen basinçli hava ile çalişan sistemiere pnömatik sistemler denir. Pnómatik, yunanca da hava ve rüzgar anlamına gelen pnöma'dan türetilmiştir. Birim enerji maliyetlerinin gittikçe artmakta olduğu günúmúzde sıkıntısı çekilmeyen havanın basınç altında kullanılması ucuz ve geniş uygulama alanlarının doğmasına neden olmuştur. Sıkma, gevşetme, ilerletme, doğrusal ve dairesel hareket pnömatikje elde edilebilmektedir (Karacan 1994). Pnömatik sistemlerde kullanılan hava atmosferde bol olarak bulunabilmekte ve boru hatları ile çok uzak mesafelere iletilebilmektedir. Basınçı havanın ateș alma tehlikesinin olmamasi nedeniyle yanici ve patiayici ortamlarda kullanilabilmektedir. Havanin temiz olmasi ve çevreyi kirletmemesi, hijyenin önemli olduğu gida sektörü gibi alanlarda yaygın olarak kullanımasına olanak sağlamaktadir. Pnömatik sistemin devre elemanlarınin büyük bölümünün hafif, basit yapıda ve kolay monte edilebilir olması seri imalat ortaminda arızanin kısa zamanda fark edilebilmesini ve üretimi aksatmadan sorunun giderilmesini sağlar. Pnömatik sistem elemanlarının çeşitliliğinin fazla olması tasarımcıya ve kullanicıya problemlerde değișik seçenekli çözüm olanaklari sunabilmektedir. Devre elemanlarınin depolanma ve nakliye giderleri düşüktür. Tozlu ve kirlı su bulunan ortamlarda çalışma olanağı sağlamaktadır. Pnömatik sistem ite doğrusal ve dairesel yơnde yüksek hızlar elde edilebilmektedir. Aşırı yükiemelere karșı emniyetlidic. Ani ivmelenme ve hassas durma hareketleri ile yüksek ilk nareket kuwveti elde edilebilmektedir (Anonim 1991).
Pnömatik sistemin bu olumlu yönlerinin yaninda birtakım olumsuz yönleri de bulunmaktadır. Havanın sıkışabilir olması hızın istenilen değerlerde sabit tutulmasinı zorlaştırmaktadır. Neme karşı dayanıksız metallerde paslanma meydana gelebilmektedir. Uygun filtre ve yağlayıcı kullanılmadığında sürtunme artmakta ve verim đüşmektedir. Çalışma basıncının düşük 6-7 bar olmasi itme ve çekme kuvvetlerinin büyük olmasinı engellemektedir (Karacan 1994). Pnömatik sistemler makine ve takım tezgahlarının konstrüksiyonundan, tarım ve hayvancilığa, kağit ve deri endüstrisine kadar pek çok sektörde kullanilmaktadir.

Paketlemeyle, çevre ile ürün arasinda bir engel oluşturulur ve ürünứn raf ömrü artırilır. Paketlemede kullanılan malzemeler tașima kapları ve koruyucu sandiklar (tahta, metal, fiber kasalar, variller, çuvallar vb.) ile perakende satış ve reklam amacıyla kullanılan malzemeler (esnek plastik çanta, poșet, plastik täpler, esnek filmler, cam şişeler, metal konserve kutuları vb) olmak üzere iki ana grupta toplanabilirler. Urünlerin paketlenmesini sağlayan makineler değişik şekillerde sınıflandırılmaktadır. Bizım üzerinde duracağımız; esnek termoplastik filmlerin şekillendirilip doldurulup kapatıldığı paketleme makineleridir. Filmin akış şekline göre paketleme makineleri dikey ve yatay akışı olarak iki tiptir (Duman 2000). Pnömatik ve paketleme makineler konusunda gittikçe artan bir şekilde pek çok çalıșma yapilmaktadit. Ömeğin Stewart ve Jefferis (1995) eserlerinde havanın ve yağın elle ve otomatik olarak

\footnotetext{
Ankara Univ. Ziraat Fak. Tarin Makineleri Bölümu-Ankara

${ }^{2}$ Uitio-Enerpac-Ankara
} 
çalıştırılan makinelerin Kontrolune dèvre şemasıyla birlikte nasil uygulanacağın adim adim anlatmıştır Steppanoff (1955), turboflowers adli çalışmasında santrifuj akışı kompresorlerin ve fonlarin teori, tasarim ve uygulamasina ilişkin bilgiler vermiștir. Hemeon (1955), basınçlı havanın iletimi ve yak kayiplari azerinde durmuştur: Peurifoy (1956), sıkıştınimış hava hakkında temel bağıntıları, enerji gereksinimi, kompresörler, hava soğutucuları ve yük kayiplari konularını açıklamiştir. Graham (1957), havanın iletim ozellikleri hakkında bilgiler vermiştir. Pippenger ve Koff (1959), basınç Ureteçleri, basınç valfleri, hidrolik devreler, ayar ve bakımı konuların açıklamışlardir. Hersom ve Hulland (1980), paketleme makinelert, paketleme malzemeleri hakkında ayrıntıl açıklamalarda bulunmuştur. Erdoğan (1984), makine malzeme bilgisi adlı ders kitabinda plastik malzemeler hakkinda bilgi vermiştir. Guise (1987), yatay paketleme makinasinda süreci etkileyen faktörleri Incelemiştir. Fellows (1992), paketieme makinelerı hakkında bilgi vermiştir. Milli Eg̈itim Bakanlığı'nın yayınladığı Pnömatik (Anonim 1994 c), Pnömatik arıza arama becerisini geliştime (Anonim 1994 b) ve Temel pnomatik (Anonim 1994 a) çeviri kitaplarında pnomatik sistem ve elemanlari konusunda ayrintili bitgiler sunulmuştur.

Bu çalışmanın amacı, yatay paketleme makinasında selofan kaynak yapma mekanizmasınin pnomatik kontrolüna ve tasarimini yapmaktadir.

\section{Materyal ve Yontem}

Çalişmada HMi5s tipi yatay paketleme makinasi ele alinmıştır. Toz ve granül gida maddelerinin paketlenmesinde kullanilmaktadir. Makinanin kapasitesi $165 \times 130 \mathrm{~mm}$ 'lik blçullerindeki 80 gramlık poşetler için ortalama 28-32 adet/min'dit. Makine dort ana bolumde incelenebilir. Bunlar, hareketin kontrolu ve dağitimi, dolum işlemi, ısıl işlemler ve țermoplastik filmin akışı lle poşet şeklinin verilmesidir.

Hareketin kontrola ve dağıtımı kanalı bir mil ile yapitmaktadir Kamali mil ortasindan delik milli ve kesik bir dişli redoktore yataklanmıştı́. Alt, ust ve yan kaynak çeneleri, ust ve alt lletici, vakum afleme ve makas hareketini kamali milden almaktadir (Şekil 1). Unitelerin hareket hızı kamalı milin dôrme hızina ve zamanlaması da milin konumuna bağlidir. Kamali mil ozerinde değışik. açılarda yerleştirilmiş mekanizmaları kamlar harekete geçirir ve bu mekanizmalar birbirleriyle uyum içerisinde çatışırlar.

Toz materyallerin dolumunda burgu lle dozajlama yapan sistem ve granul materyallerin paketlenmesinde bacimsel dolum sistemi kullanilmaktadir.

Poset kenarlarinin Isil ișlemle kapatilmasinda çeneler kullanilmaktadır. Çene tek parça metalden yapilmıştır Çené içerisinde bulunan yuvaya termorezistans ve termokupl yerleştirilit. Makine uzerinde 4 çene çifti vardir.

Termoplastik filmin ilk akışı makine hızına göre otomatik olarak film bobininin açılmasi ile olur. Film makine girișindeki düzenek aracilığıyla poşet şeklini alir. Bazı poşet tiplerinde filmin alt tarafı katlanit ve kaynak yapilmaz Bu durumda alt çene çaliștirilmaz Katlanmiş filmin makine içerisindeki hareketi bir tutucunun filmi ustten kayrayıp sağ tarafa hareket ettirmesi ile olur.

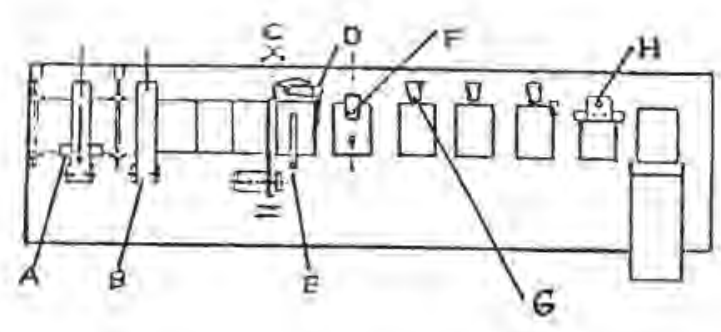

Sekil 1. Kamalı milden hareket olan Oniteler (A: Alt kaynak çenesí, B:Yan kaynak senesi, C: makas, D: Tutucu, E:Film duzelticilen, F:Vakum, G;Dolum, H:Ust kaynak çenesi)

Tutueu, makas ile vakum arasindadir Tutucunun görevi ana filmi bir paket boyu ilerletip makasın keseceği konumagetirmektir. Film akışınin durması ite çeneler kapanır ve makas filmi keserek bir poşeti ana filmden ayırır. Vakum ve uffeme lle poşet dolum konumuna getirilir ve dolum düzeneği devreye girer.

Filmin tekrar hareketienmesi lle tom uniteler eski konumiarını alırlar. Poşetin ana filmden ayrılmasından sonraki ileri hareketini alt iletici gerçekleştirir. Alt iletici iki ayrı ray sisteminden meydana gelir. Rayların dışa doğru açilıp kapanması ile poșet lletilir. llerleme yönünde vakum, ufleme, dolum ve üst kenar kaynağı yapilir (Duman 2000).

Vakum vantuzlari poşetin yan yözeyinden etki eder ve vakum kuweti ile poşetin ağzı açilır. Bu sırada ofieme yapilarak poşetin içi havayla doldurulur ve dolum için poşete biçim verilmiş olur. Makinada kullanilan ve araştırmada ele alınan filmin bazı ozellikleri imalatçı firmanın verilerine gore çizelge 1'de verilmiștir.

Paketleme makinasinda selofan kaynak yapma makanizmasinin pnömatik kontrolünü yaparken pnömatik ekipmanların seçimi Festo'nun kataloglarından yararlanilarak yapilmiștic. Festonun (Anonim 1998) göz onone alınmasının nedeni, Torkiye'de geniş çaplı hizmet ve eğitim ağının olması, yaygın olarak kullanılması ve kolay bulunabilmesidir, Sistemde kullanilacak pistonlarin geliştirebileceği kuvvetler:

$$
\mathrm{F}=\mathrm{PA} \mu
$$

bağıntısıyla hesaplanmıştır. Burada $F$ : piston kuvveti (daN), $P$ basınç olup 6 bar alınmıştır. A: piston yúzey alani $\left(\mathrm{cm}^{2}\right)$ ve $\mu$ :verim alup 0,85 alinmıştir (Karacan 1994) Silindirin tôkettiği hava miktarının (Q) bulunmasında

$$
\mathrm{Q}=\frac{\pi \mathrm{D}^{2}}{4 \cdot 10^{6}} \mathrm{hP}
$$

bağıntısı kullanılmıştır. Burada; $Q$ : toketilen hava ( $L$ ), $P$ : basinç (6 bar), ht strok ( $\mathrm{mm}$ ) ve $P$ piston çapi $\mathrm{mm}$ )'dir. Kompresör ve şartlandırıcı seçiminde en önemli faktör olarak tum sistem için gerekli olan hava miktari göz onane almmiştır. Yôn ve basinç kontrol valflerinin seçiminde en onemli etkenler hava debisi ve basınçtır, Vakum Initelerinde vantuzların seçiminde bağlantı sekilleri. vantuz çaplar, emme kuvvetlen ve makemeleri onemil faktorlerdir. Tutucuların seçiminde tutma biçimi, parmaklaın açilip kapanma frekansları, parmakiarın ôlçoleri ve yapildiği malzeme cinsi ve toplam ağırikları onemli olmaktadir (Duman 2000) 
Cizelge 1. Kullanilan termoplastik filmin ōzellikleri ve optimum çalışma araliğı (Duman 2000)

\begin{tabular}{|c|c|c|}
\hline Kalite faktörleri & $\begin{array}{l}\text { Kalite faktór } \\
\text { değerieri }\end{array}$ & Toleranslar \\
\hline Fotosel aralığı (mm) & 130 & $\pm 1,5$ \\
\hline Bobin eni (mm) & 380 & $\pm 0,5$ \\
\hline $\begin{array}{l}\text { Laminasyon gucia* } \\
(\mathrm{g} / \mathrm{mm})\end{array}$ & $150 / 25$ & - \\
\hline $\begin{array}{l}\text { Laminasyon } \\
\text { duzzüniüğo }\end{array}$ & $\begin{array}{l}\text { Kirișma ve } \\
\text { Kabarma yok }\end{array}$ & - \\
\hline $\begin{array}{l}\text { Isil yapişma (Çene } \\
\text { testi) }\end{array}$ & $\begin{array}{c}150^{\circ} \mathrm{C} / 33 \mathrm{ps} / / 1.5 \\
\mathrm{~s} .\end{array}$ & - \\
\hline $\begin{array}{l}\text { Soğuk yapışma } \\
\text { (g/mm) }\end{array}$ & $250 / 25$ & - \\
\hline Murakkep miktari (g) & 1,21 & - \\
\hline Toplam gramaj $(\mathrm{g})$ & 93,86 & - \\
\hline Toplam kalınlik ( $u m$ ) & 92 & - \\
\hline
\end{tabular}

* Kaynak bölgesinin açiması için gerekli kuwvel

\section{Bulgular ve Tartișma}

\section{Alt ve üst kaynatma çenelerinin tasarum}

Makinenin kapasitesi hedeflenen maksimum poșet olçcleri olan $210 \mathrm{~mm} \times 160 \mathrm{~mm}$ için 40 adet/min hedeflenmiştir. Kapalı pozisyanda, çenelerin makine govdesinden $120 \mathrm{~mm}$ lik mesafesinde birleșmesi tasarlanmiștir. Iki çenenin açik olduğu pazisyanda filmin rahat akışı ve penelere yapışan maddelerinin temizlenebilmesi için $\mid \mathrm{ki}$ çene arasında yeterli mesafe olmasi ggerekmektedir: Ait ve üst keynatrna çene gruplarında baskı ve yastıklama gốrevi yapan iki ayn çene sistemi yer almaktadir. Baski grubunda, ejift etkifi silindir (çekme kuwvelinden faydalanlacaktır), 5/2 selenoid yön kontrol valfi, pozisyon algilayicl sensōr, çekme yönunde basinç ayar valfi, hava jletimi için gerekli ara bağlantı elemanlari, kizak unitesi, rezistans yardimiyla isitilan çene, uzatma mili ve bağlantı plakasinın kullanilması dūşunulmūştūr. Baskı çenesinin, birleşme nokiasindan geri yönde 40 mmilik strok seçimiștir Silindir ve çene grubunun bağil olduğu bağlantı plakasi arasindaki 230 mm'lik mesafede piston ucuna 190 mm'lik $16 \mathrm{~mm}$ çapında mil vidalı bağlantı ile eklenmiştir. Yastıklama grubunda; çift etkili silindir (itme kuvvetinden faydalanilacaktir), 5/2 selenold you kontrol valfi, pozisyon algilayıcı sensor, hava iletimi için gerekll ara bağlantı elemanlari, kizak anitesi, rezistans yardimıyla ısıtılan çene, uzatma mili ve bağlant plakası kullanılacaktır. Yastıklama çenesinin, birleşme noktasindan geri yönde $25 \mathrm{~mm}$ lik hareketi ile frimin akıși ve gerekli durumda çenenin temizlläl için intiyaç duyulan mesafe elde edilebilmektedir. Bu sebeple silindirde standart $25 \mathrm{~mm}$ ' lik strok seçilmiştir. Silindir ve çene grubunun bağlı oiduğu bağlantı plakasi arasındaki $70 \mathrm{~mm}$ lik mesafede piston ucuna $45 \mathrm{~mm}$ ' lik $16 \mathrm{~mm}$ çapinda mi eklenmiştir. Her iki grupta da silindirler kızak ünitesi lie makine govdesine monte edilmișlerdir. Kızak uzerinde bulunan, bilyali yataklanmış iki mil ile piston kolu azerine gelen yük azaltilmıştır. Gene uzerindeki termoplastik film lie temas eden kaynak bölges], $160 \mathrm{~mm} \times 15 \mathrm{~mm}$ blçolerindedir. Baskı grubu sllindir seciminde baskı kuwetinin uygulanacağ yozey alant $24 \mathrm{~cm}^{2}$, toplam yuzey alani için gerekli kuvvet 54,6 daN, gerekli toplam kuvvel verecek piston yüzey alani $A=10,7 \mathrm{~cm}^{2}$, piston çapl 40 $\mathrm{mm}$ piston kalu çapi $16 \mathrm{~mm}, 40 \mathrm{~mm}$ strokfu bask silindirinin itme konumu için hava tóketimi $0,3 \mathrm{~L} / \mathrm{strok}$ cekme Konumu için 0,25 L/strok, baskt grubu silindirin toplam hava tuketimi $0,3+0,25=0,55 \mathrm{~L} /$ strok bulunmuștur. Yönlendirme valfinin ve valfin seçıminde ayni işlemin 40 kez tekrarlanmasi nedeniyle $0,55 \times 4=2,2 \mathrm{~L} / \mathrm{min}$ hava debisi göz önüne alınmıştır. Basınç kontrol vali $0-8$ bar arasinda ayarlama yapabilmelidir. Yastiklama grubu silindir seçiminde Fyastık $\geq$ Fbaskı olmalidır. Buna göre silindirin itme kuwveti Fyastik=64,1daN hesaplanmıştir. $25 \mathrm{~mm}$ stroklu yastıklama silindirin hava tüketimi itmede 0,19 Listrok ve çekmede 0,16 L/strok olmak izere toplam 0,35 Listrok' tur. Yönlendirme valfinin seçiminde 0,35 L $\times 4 D=14$ Limin göz önone alınmıştır (Duman 2000).

\section{Yan kaynak çene tasarımi}

Yan kaynak çene tasariminda bir çene grubu kullanilacaktır, Çenenin hareketi için çift etkili silindir seçilmiştir. Kapalı pozisyonda, çenelerin, makine gôvdesinden $120 \mathrm{~mm}$ lik mesafede birleşmesi tasarlanmıştır. Iki çenenin açık olduğu pozisyonda filmin rahat akişi ve çenelere yapișan maddelerinin temizlenebilmesi için iki çene arasinda yeterli mesafe olması gerekmektedir. Alt ve usł kaynatma çene gruplarinda oldug̃u gibi, yatay kaynak çenelerinde baskı ve yastıklama gorevi yapan iki ayn çene sistemi yer almaktadır. Baskı grubunda, çift etkili silindir (çekme kuvvetinden faydalanilacaktir), $5 / 2$ selenoid yön kontrol valfi, pozisyon algilayic| sensör, çekme yönünde basinç ayar valfi, hava lletimi için gerekli ara bağlantı elemanları. kizak ûnitesi, rezistans yardimiyla isıtilan çene, uzatma mifi ve bağlantı plakası kullamilacaktı. Açık pozisyonda iki çene arasindaki gerekli boşluk için silindirde standart 40 mm'lik strok seçilmiştir. Silindir ve çene grubunun bağli olduḡu bağlantı plakası arasındaki $210 \mathrm{~mm}$ 'lik mesafede piston ucuna $170 \mathrm{~mm}$ lik $16 \mathrm{~mm}$ çapında mil vidalı bağlantı ile eklenmiștir. Yastıkłama grubunde; cift etkili silindir (itme kuwetinden faydalanilacaktır), $5 / 2$ selenoid yón kontrol valfi, pozisyon algilayici sensor, hava iletim için gerekli ara bağlantı elemanları, kızak unitesi, rezistans yardımıla isitilan çene, uzatma mili ve bağlantı plakası bulunacaktır. Açik pozisyonda iki çene arasindaki gerekli boșiuk için silindirde standart $25 \mathrm{~mm}$ 'llk strok seçilmiştir. Sillindir ve çene grubunun bağli olduğu bağlantı plakası arasındakı $87 \mathrm{~mm}$ lik mesafede piston ucuna $62 \mathrm{~mm}$ 'lik $16 \mathrm{~mm}$ çapinda mil eklenmiştir. Her iki grupta da silindifler kızak anitesí ile makine gövdesine monte edilmişlerdir. Kızak uzerinde bulunan, bilyalı yataklanmış iki mil ile piston kolu üzerine gelen yük azaltılmiştır. Gene üzerindeki teimoplastik film ile temas eden kaynak bölgesi $210 \times 30$ $\mathrm{mm}$ ölçülerindedir. Baskı grubu silindir seçiminde baski kuwetinin uygulanacağ| yüzey alan $21 \times 3=63 \mathrm{~cm}^{2}$, gerekli baskı kuvveli toplam yüzey alan için $63 \times 2,2737$ daN $(33 \mathrm{psi})=143,2$ daN, toplam kuvveti verecek piston yozey alanı $28,1 \mathrm{~cm}^{2}$, piston çapi $63 \mathrm{~mm}$, piston kolu çapi $20 \mathrm{~mm}$, silindirin toplam hava toketimi $0,75 \mathrm{~L} /$ strok itme ve $0,68 \mathrm{~L} / \mathrm{strok}$ çekme olmak azere toplam $1,43 \mathrm{~L} / \mathrm{strok}$ olarak hesaplanmışır. Yönlendirme ve basınç kontrol valflerinin seçiminde 1,43 × 40=57,2 L/min hava debisi kullanilmiștir. Yastiklama grubu silindir seçiminde silindirin itme kuvveti 158,9 daN olup, baskı için seçilen çekme kuvvetinden $(134,2$ dalN ) daha boyoktur $25 \mathrm{~mm}$ stroklu yastikłama silinditinin hava toketimi itmede $0,75 \mathrm{~L} /$ strok çekmede 0,70 Listrok ve toplamda 1,45 L/strok tur Seçilecek yorilendime valfi $1,45 \times 40=53 \mathrm{~L} / \mathrm{min}$ debiyi sağlamalıdır (Duman 2000). 


\section{Makas tasarum!}

Makasin iki kolunun kontrola tki adet silindir lie sağlanacaktır. Pistonların ileri geri hareketleri kontrol edileceğinden silindirler çift etkili olarak seçilecektir. Pistonların hareketleri sensör yardımıyla takip edilecektir Sillindirin piston hareketi $5 / 2$ selenoid kumandali akis kontrol valfi ile kontrol edilecektir. Silindirler birer flanşla makjne gövdesine monte edilecektir. Makasın her ik kesme ağzinda uygulanmasi gereken kuvvet yaklaşık 7,5 daN olması durumunda uygun piston yuzey alanı $A=$ $F / P, \mu=7,5 / 6 \times 0,85=1,47 \mathrm{~cm}^{2}$ olarak hesaplanabilit. Seçilecek silindirin piston kolu, burulmanin engellenmesi için kare kesitli olmafidir. Sillindirlerin strokları $20 \mathrm{~mm}$ seçilmiştir. Standart silindirlerin piston çapi ve piston kolu kenar blcuso D-f. $12-5,5, / 16-5,5 / 20-7$ mm'dir. Bu verilenlere gore çekme kuvvetini sağlayacak silindirin çekme kuvveti 8,67 daN, piston çapi $16 \mathrm{~mm}$, piston kolunun bir kenari $5,5 \mathrm{~mm}$ bulunur. Itme kuvvetinden yararlanacak silindirin piston çapı yine $16 \mathrm{~mm}$ ve piston kolunun bir kenarı $5,5 \mathrm{~mm}$ alınırsa sağlayacağı kuvve! 10,2 daN elde edilir. Sillindirlerin hava taketimi itme icin $0,024 \mathrm{~L} /$ strok, çekme için 0,023 Lstrok ve toplam 0,047 L/stroktur. Yönlendirme valfleri $40 \times 0,047=1,88 \mathrm{~L} / \mathrm{min}^{\prime} \mathrm{e}$ göre seçilit. Basınç kontrol valfide 1,88 L/min'e göre seçlimeli ve 0 ile 8 bar arasında ayarlama yapilabilmelldir (Duman 2000).

\section{Ust iletici tasarımı}

Görevi, düzeltme çubuklanndaki ana filmi bir poşet boyu kadar çekip, makasın poşeti ana filmden ayımasının ardindan alt ileticiye kadar taşımaktir. Ust iletici işlemini 3 kademede tamamlamaktadir. Üst lleticide piston kolsuz çitt etkill silindir, hareket algilama sensorleri, $5 / 3$ selenoid kumandall akıs kontrol valii, paralel tutucu (gripper), tutucu için $5 / 2$ selenoid kumandalı akıș kontrol valfi ve algglama sensöro, ara bağlantı parçası, düzeltíci çubuklar, silindir bağlantı flanşları, fotosel (makinenin film giris tarafina, alt kaynak çenesinden konur) kullanilmaktadir. Silindir strogu seçilitken, 160 mmlitik maksimum poşet genișingi ve alt ileticiye rahat hareket alanı birakacak olan $40 \mathrm{~mm}$ lik mesafe goz önande bulundurulmuştur. $200 \mathrm{~mm}$ 'lik strok toplam üc konumda hareketi tamamlamak için yeterlidir. Silindirin sağ ve sol ölö noktalarındaki, hizli hareketten kaynaklanan, darbeleri azaltmak için yastıkłamail pistonlu silindir kullanilı. Tutucu seçilirken ihtiyaç duyulan 15 mm'lik açıklık dikkate alınmıştır. Tutucu parmakları nilkel kaplamall celikten imal edilebilit. Termoplastik nilme zarar vermemesi Için parmakların arasına darbe emici ve tutunmayi arttiran kauçuk tura kat koyulabilir. Kauçuk katlar ve gerekll açıklk için standart 25 mmlik açikliğı sağlayan $35 \mathrm{~mm}$ piston çapına sahip tutucu seçilmiştir. Silindirin montajı baş aşağı gelecek şakilde tasarlanmıştir. Tutucunun ve diğer yan etkilerin oluşturduğu duş̧y kuvveti de karşllamak için standart $18 \mathrm{~mm}$ piston çapina sahip piston kolsuz çift etkill sillindir seçilmiştir. Piston kolsuz cift etkill silindirin piston yozey alani her ikj tarafta da aynidir Silindirin sağlayacağı kuWvet 13 daN sillindirin hava toketimi $0,3 \mathrm{~L}$ strok bulunmuş, yôniendime valfinin seçiminde 12 Umin hava debisi gōz önune घilinmig̨tir. Seçilen tufucunun paralel parmaklarinin uygulayacagi kuvvet $45 \mathrm{daN}$ ve silindirin hava tuketimi 0,11 i/stiok bulunmuş plup yönlendime valfinin seçiminde $5,6 \mathrm{~L} / \mathrm{m}^{\prime} \mathrm{n}^{\prime} \mathrm{llK}$ debi kullanilmiştir (Duman 2000).

\section{Alt iletici tasarımi}

Görevi; ust ileticiden, Uę tarafı Kaynakianmiş halde bit adet poşeti alarak toplam 4 kademelik hareketi ile sırasıyla ülleme-vakum, dolum ve üst kaynak işlemlerinin tamamianmasini sağlamaktır. Her bir kademedeki konumu konum algılama sensärleri ile belirlenir. All ileticide piston kolsuz çift etkill silindir, hareket algılama sensörieri, $5 / 3$ selenoid kumandalı akıs kontrol valfi, $i k i$ adet paralel tutucu (gripper), tutucular için 5/2 selenoid kumandalı akıs kontrol valfleri ve algilama sensorleri, ara silindir ve $5 / 2$ selenoid akıs kontrol valfi ile algılama sensörù, ara bağlantı parçası, silindir bağlantı flanşları. Piston kolsuz silindir uzerinde bulunan tașıyıcı parçanin uzerine, poşeti Iki tarafından futabilmek için iki adet tutucu yerleştirilmiştir. Tutucular, ust ileticide olduğu gibi $25 \mathrm{~mm}$ lik açilma mesafesine sahip $35 \mathrm{~mm}$ piston çaplı paralel parmaklı tipler seçilmiştir. Iki tutucu arasında bir adet $30 \mathrm{~mm}$ stroklu ve $20 \mathrm{~mm}$ piston çapil çif etkili sillindir kullanilmiștir. Tutuculardan birisi ve ara silindir taşıyıcı parçaya sabitlenmiștir. Diğer tutucu ise ara silindirin piston kolu tarafından taşınmaktadir. Tutucular arasinda gergin halde bulunan poșet, ara silindirinin $5 \mathrm{~mm} / \mathrm{lik}$ geri hareketi ile uflemevakum ve dolum esnasında daha kolay form alabilmektedit. Ust kaynak esnasında ara silindiri $30 \mathrm{~mm}$ 'lik stroguna ulașmaktadir ve kaynak poşetin gergin olduğa anda yapilabilmektedir. Piston kolsuz silindir stroğu seçilirken, taşıyıcı parça genişıgl olan $3 \times 190 \mathrm{~mm}$ ve arada birakilacak $3 \times 110$ mm'lik mesafe göz onunde bulundurulmuştur. $900 \mathrm{~mm}$ 'lik strok, toplam dört konumda hareketi tamamlamak için yeterlidir. Seçilen silindirin piston çapi Binm'dir. Piston kolsuz çift etkili silindirin piston yazey alanı her ikı tarafta da ayndır. Silindirin sağlayacağl kuvvet 2,55

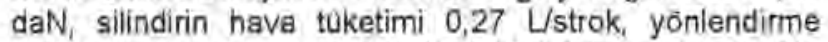
valfinin seçimi için hava tüketimi 10,8 L/'min olarak elde edilmiştir. Seçilen tutucuların paratel parmaklarının uygulayacağı kuwet $45 \mathrm{daN}$, hava tuketimi $0,28 \mathrm{~L} /$ strok olup her iki tutucu için bif yônlendirme valfi kullanilacaktir. Seçilecek yonlendirme valfi $11,2 \mathrm{~L} /$ min debiyi sağlamalıdır: Kullanilan ara silindirin sağlayacaği kuvvet 16 daN, hava tüketimi 0,06 L/strok yönlendirme valfinin seçimini etkileyen hava debisi ise 2,42 L/min'dir (Duman 2000).

\section{Vakum ve Ifleme elemanlarinin tasarımı}

Vakum elemanlarınin gorevi; gerginliği alınmıs vaziyette alt lletici uzerinde bulunan poşetin her iki yüzeyine yaklaşarak vakumlamak suretiyle poșetin ağzını açarak dolum hunisinin içine rahatikka girip çıkmasını sağlamaktır. Karşlıkı iki adet vantuzun ileri ve geri nareketlerinin kontroid $25 \mathrm{~mm}$ stroklu iki adet çift etkili sllindir lle sağlarmaktadir. Pistonlarin hareketlerí sensór yardimıyla izienmektedit, Pistonlarin hareketi $5 / 2$ selenoid kumandali akıs kontrol valfi ile kontrol edilmektedir. Silindirlerin eşit miktarda kưvet uygulamesı için itme silindiri tarafina basinç kontrol valfi eklenmektedir. Silindirler birer flanşla makine gōvdesine mante edilmektedir. Vakum elde etmek için vakum jeneratöri kullanilmaktadir, Vakum, vakum elemant vasitasıyla vantuzlara llatilmaktedit. Termoplastik filmin ideal vakumlanmasi için PU vantuzlar kullanimaktadir. Ufieme bolumu ise vakumla açilan poșetin içine hava vererek dip kısımlarin da açilmasinı sağlar Ofleme, bir boru vasitası ile poşetin içine yapilir. Boru, doșey monte edilmis bir silindir yordimi ile așaği yukari hareket edebilmektedir. 
Borunun istenilen yere ufleme yapması ve affemenin ardından poşetin engellenmeden ilerlemesi için silindirin stroğu $20 \mathrm{~mm}$ seçilmiștir. Vakum ve üfleme bölümlerinde kullanilan silindirlerin piston kolları, burulma olmaması için kare kesitli seçilmiştir. Seçilen standart silindirin piston çapı ve piston kolu kenar olçüsü sirasiyla 8 ye $4,5 \mathrm{~mm}$ 'dir. Çekme kuwetinden yararlanacak vakumlama silindirinin sağlayacağı kuvvet 1,53 daN ve itme kuvvetinden yararlanacak silindirin sağlayacağı kuvvet 2,55 daN'dur. Silindirlerin hava tüketimi itme için $0,008 \mathrm{~L} / \mathrm{strok}$, çekme için $0,005 \mathrm{~L} /$ strok ve yönlendirme valfinin seçiminde kullanilacak hava toketimi ise $0,44 \mathrm{~L} / \mathrm{min}$ bufunmuştur. Basınç kontrol valfi de $0,44 \mathrm{~L} / \mathrm{min}$ debiyi sag̊lamalı ve 0 ile 8 bar arasında ayarlama yapilabilmelidir. Üfleme silindiri piston çapi ve piston kolu kenar olçüsu, vakumlama silindiri lle aynıdır. Bu nedenle çekme ve itme kuvvetleri de aynidir. Ancak strokunun $20 \mathrm{~mm}$ olmasindan dolayı hava tôketimi değişmekte ve itme için $0,006 \mathrm{~L} / \mathrm{strok}$ çekmek için 0,004 L/strok olmaktadır. Seçilecek yönlendirme valfi minimum 0,32 L/min debiyi sağlamalıdır (Duman 2000).

\section{Sonuç}

Materyal ve yöntem ile bulgular ve tartışma bolümundeki verilere bağlı olarak ilgili ekipmanlar (Anonim 1998)'den aşağıdaki gibi seçilmiştir,

\section{Alt ve üst kaynatma çeneleri}

Baskı grubu silindirleri ve diğer elemanları : Seçilen çift etkili silindirin tipi : DNG-40-40-PPV-A. Piston çapi: $40 \mathrm{~mm}$, Piston kolu capi: $16 \mathrm{~mm}$, Strok: $40 \mathrm{~mm}$, Max. çalışma basınct: 12 bar'dır. Ozellikleri: Yağsız hava ile çalışabilme imkani, manyetik algilama, ayarlı son konum yastıklamalı, alöminyum sllindir kovanr, haddelenmiş ve paslanmaya karşı korunmuş piston mili. Seçilen temassız algılayıcının bağlantı elamanı tipl: $S M B-2-B$, Algılayıcı tipi: SMEO- 1, Seçilen yön kontrol valfinin tipi: JMZH - 5/21,5- L - LED, manifold tipi: PRMZ-5-M5-10 Kablolu soket tipi. KMYZ-1-24-2,5, Anma Debisi: 80 L/min, Basınç Aralığı: 2-7 bar, Orta konum: Çift pilotlu valf, Fonksiyon. $5 / 2$ selenoid kumandalt, Ozellikleri. 24 VDC, $0,55 \mathrm{~W}_{i}$ LED ile çalışma ve emniyet göstergesi, yardımcı el kumandalı, taban plakası valfi. Seçilen kızağın tipi: FENG- $40-400$ $\mathrm{KF}_{1}$ Strok: $400 \mathrm{~mm}$, Piston çapı: $40 \mathrm{~mm}$, Özellikleri. Küresel yataklama, dönmeye karşı yüksek emniyet. Seçilen basinç kontrol valfinin tipi: LRMA-M5-QS6. Normal anma debisi: $40 \mathrm{~L} / \mathrm{min}$, basınç aralığı:0-9 bar, basınç ayari; 1-8 bar (manometreli).

Yastıklama grubu silindirleri ve diğer elemanlafı Seçilen çift etkili silindirin tipi: DNG-40-25-PPV-A, Piston çapl: $40 \mathrm{~mm}$, Piston kolu çapI: $16 \mathrm{~mm}$, Strok: $25 \mathrm{~mm}$, max. Çalışma basınci: 12 bar, Özellikler yağsız hava ile çalışabilme imkanı, manyetik algılama, ayarti son konum yastıklamalı, alimünyum silindir kovani, haddelenmiş ve paslanmaya karşı korunmuş piston mili. Seçilen temassız algılayıcının bağlantı elemanı tipi: SMB-2-B, algılayıcı tipi: SMEO-1. Seçilen yôn kontrol valfinin tipi: JMZH-5/2-1,5-LLED, Kablolu soket tipt: KMYZ-1-24-2,5, Anma debisi: $B O$ L/min, Basınç aralığı: $2-7$ bar, Orta konum: çift pilotlu valf, Fonksiyon: 5/2 selenoid kumandal, Ozellikleri. 24 VDC, $0,55 \mathrm{~W}$, LED ile çalışma ve emniyet göstergesi, yardimci el kumandalı, taban plakası valfi. Seçilen kızağın tipi: FENG40 - $200 \mathrm{KF}_{1}$ Strok. $200 \mathrm{~mm}$. Piston çapl $40 \mathrm{~mm}_{i}$ Ozellikleri: Küresel yataklama, dönmeye karşı yüksek emniyet. Şekil 2'de alt kaynak bölümünü oluşturan elemanların yerleşiminin yandan ve ustten görünümleri,
Şekil 3'de de ùst kaynak bölümúnün yan ve ùst göranümleri yer almaktadir.

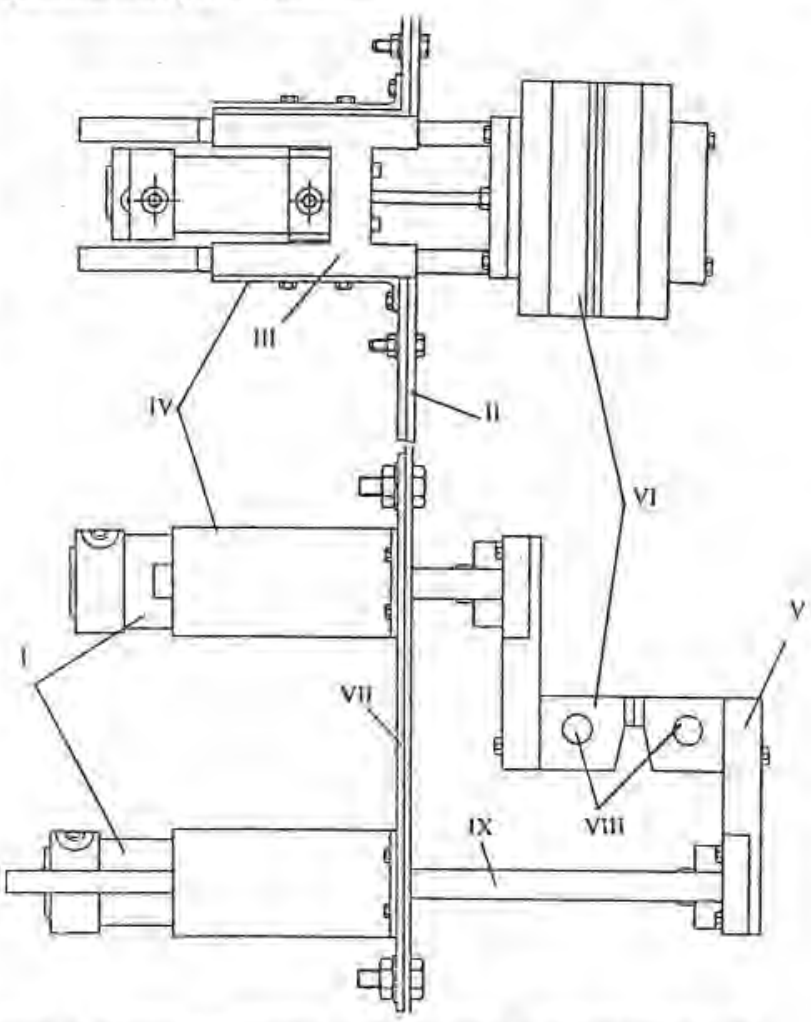

Sekil 2. Alt kaynak bölümu ustten ve yandan görünùmü (l: Çift etkilf silindir, II:Makine gövdesi. III: Kızak, IV: Kızak bağlantı flanșı V:Çene bağlantı parçası, VI: Cene, VIt:Kaydirma Plakası, VIII:Termorezistans yuvasi, (X:Piston kolu uzatma parçası) (Duman 2000)

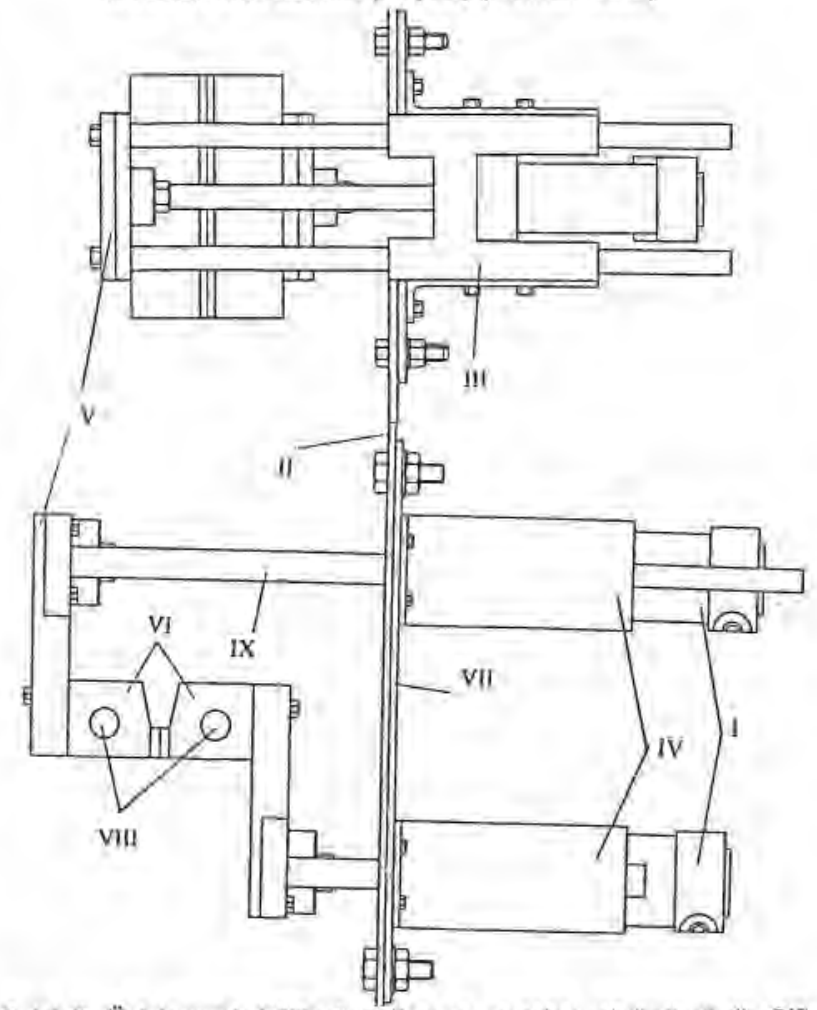

Şekil 3. Üst kaynak bölümá üstten ve yandan görünümá (i: Cift etkili silindir, II:Makine gövdesi. III: Kızak, IV: Kızak bağlantı flanșı V:Çene bağlanț parçası, Vi: Çene, VIl:Kaydirma Plakası, VIII:Termorezistans yuvasi, IX:Piston kolu uzatma parçası) (Duman 2000) 


\section{Yan kaynak çeneleri}

Baskı Grubu Sillindirleri: Seçilen çift etkill sillindirin tipi: DNG-63-40 -PPV - A, Piston çapl: $63 \mathrm{~mm}$, Piston kolu çapi: $20 \mathrm{~mm}$, Strok $40 \mathrm{~mm}$, Max.çalıșma basincl: 12 bar'dir. Ózellikleri: Yağsız hava ile çalışabilme imkanı, manyetik algılama, ayarlı son konum yastiklamali, alüminyurn silindir kovanı, haddelenmiş ve paslanmaya karşı korunmuş piston mili. Seçilen temassız algilayicının bağlantı elamanı tipi: SMB - 3-B, Algılayıcı tipi: SMTO-1, Seçilen yön kontrol valfinin tipi: JMZH - 5/2-1,5- L - LED, Kablolu soket tipi:KMYZ - 1- 24-2,5, Anma Debisi: 80 L/min, Basınç Aralığı; 2-7 bar, Orta konum: Çift pilotlu valf, Fonksiyon. $5 / 2$ selenoid kumandali, Özellikleri: 24 VDC, $0,55 \mathrm{~W}$, LED ile çalıșma ve emniyet góstergesi, yardımcı el kumandalı, taban plakası valfi, Seçilen kızaŏın tipi: FENG- 63 - 400 KF, Strok: 400 mm, Piston çapi:83 mm, Özellikleri: Küresel yataklama, dónmeye karș yüksek emniyet.

Yastıklama Grubu Silindirleri : Seçilen Sillindirin tipi: DNG- 63 - 25 -PPV -A, Piston çapl: $63 \mathrm{~mm}$, Piston kolu çapr. $20 \mathrm{~mm}$, Strok. $25 \mathrm{~mm}$, Max çalışma basınci: 12 bar'dir. Özellikjeri: Yağsız hava ile çalışabilme imkanı, manyetik algılama, ayariı son konum yastıklamalı, alüminyum silindir kovani, haddelenmiş ve paslanmaya karşı korunmuş piston mili. Seçilen temassız algilayicınin bağlantı elamanı tipi: SMB - 3-B, Algılayıcı fipi: SMTO-1, Seçilen yön kontrol valfinin tipi: JMZH - 5/2-1,5- L-LED, Kablolu soket tipi:KMYZ - 1-242,5, Anma Debisì: $80 \mathrm{~L} / \mathrm{min}$, Basinç aralığı: $2-7$ bar Orta konum: Çift pilotlu valf, Fonksiyon. 5/2 selenoid kumandali, Ozellikleri: 24 VDC, $0,55 \mathrm{~W}$, LED ile çalışma ve emniyet göstergesi, yardimci el kumandali, taban plakası valfi. Seçilen kızağın tipi: FENG- 63 - 200 KF, Strok: $200 \mathrm{~mm}$, Piston çapı:63 mm, Özellikleri: Küresel yataklama, dönmeye karșı yoksek emniyet. Kullanilan Basinç Kontrol Valfinin normal anma debisi: $70 \mathrm{~L} / \mathrm{min}$, Basınç aralığı: $0-9$ bar, Basınç ayarı 1-8 bar, Tip:LRMA-1/8-QS-8. Şekil 4. de yan kaynak bölümùna oluşturan elemanlarin yerleșimi yandan göralmektedir.

\section{Makas}

Itme ve çekme kuwetlerinden faydalanilacak silindirler: Seçilen çift etkill silindirin tipi: DSNUL- $16-25-P P V-A$, Piston çapl: $16 \mathrm{~mm}$, Piston kolu kenar uzunluğu: $5.5 \mathrm{~mm}$, Strok: $25 \mathrm{~mm}$, Max.çalişma basinci: 10 bar Özellikleri Yağsız hava ile çalışabilme imkanı, manyetik algilama, ayarlı son konum yastiklamali, aluminyum silindir kovani, haddelenmiş ve paslanmaya karşı korunmuş piston mili, dönmeyen piston kolu. Seçilen temassız algılayıcınin bağlantı elamanı tipi: SMBR -16, Algılayıcı tipl. SMTO- 4 U. Seçilen yön kontrol valfinin tipi: JMZH - 5/2-1,5- L LED, Kablolu soket tipi:KMYZ - 1-24-2,5, Anma Debisi: $80 \mathrm{~L} / \mathrm{min}$, Basınç Aralığı: 2-7 bar, Orta konum: Çift pilotlu valf, Fonksiyon, $5 / 2$ selenoid kumandalı, Özellikleri: 24 VDC, $0,55 \mathrm{~W}$, LED ile çalışma ve emniyet göstergesi, yardimcı el kumandalı, taban plakası valfi. Seçilen flanșin tipl: $\mathrm{HBN}-16-5$, Kullanilan basinç kontrol valfinin normal anma debisi; $20 \mathrm{~L} / \mathrm{min}$, Basınç arahı̆ı: $0-9 \mathrm{bar}$, Basınç ayar!: 1-8 bar, Tipi: LRMA-M5-QS-4. Sekil 5'de makasin yan görünùişü verilmiş̧tir.

\section{Ust iletici}

lletici silindir: Seçilen çift etkili piston koisuz silindirin tipi: DGP-18-200-P -A-B, Piston çapl: $18 \mathrm{~mm}$, strok: $200 \mathrm{~mm}$, Max.çalışma basıncı: 8 bar, Ozellikleri: Manyetik algılama, ayarlı son konum yastıklamalı, küçük montaj alaninda uzun strok sağlayabilirler. Seçilen temassız algilayicinm tipi: SME - 8-K- LED-24, lletici sillndir icin seçilen yön kontrol valfinin tipi: $M Z H-5 / 3-1,5-L$ - LED, Manifold tipi: PRMZ-5-M5-2, Kablolu soket tipi KMYZ - 1$24-2,5$, Anma debisi: $45 \mathrm{~L} / \mathrm{min}$, Basınç aralığı: 2-7 bar, Orta konum: Egzoz, Fonksiyon: $5 / 3$ selenoid kumandal, Özellikleri: 24 VDC, 0,55 W. LED jle çalışma ve emniyet göstergesi, yardımcı el kumandall, taban plakası valif Seçilen tutucunun tipi: HGP-35-A, Piston çapi: $35 \mathrm{~mm}$ Yapisi: Iki parmak paralel, Tekrar hassasiyeti: $\pm 0,02 \mathrm{~mm}$, Açima miktarr: $25 \mathrm{~mm}$, Maksimum çalışma basınce: 8 bar, Ozellikleri: Yağsız hava ile çalışabilme imkanı, manyetik algılama, yüksek tekrar hassasiyeti, sabit tutma momentleri. Seçilen temassiz algilayıcının tipi: SME - 8-K-LED-24, Tutucunun kontrolünde kullanilan yön kontrol valfinin tipi. JMZH $-5 / 2$ 1,5- L - LED, Kablolu soket tipi: KMVZ - 1- 24-2,5, Anma debisi: $80 \mathrm{~L}$ min, Basınç aralığı: $2-7$ bar, Fonksiyon. 5/3 selenoid kumandalı, Ozellikleri: 24 VDC, 0,55 W, LED lle çalişna ve emniyet göstergesi, yardimci el kumandali, taban plakası valfi, Şekil 6'da ust iletici görülmektedir.

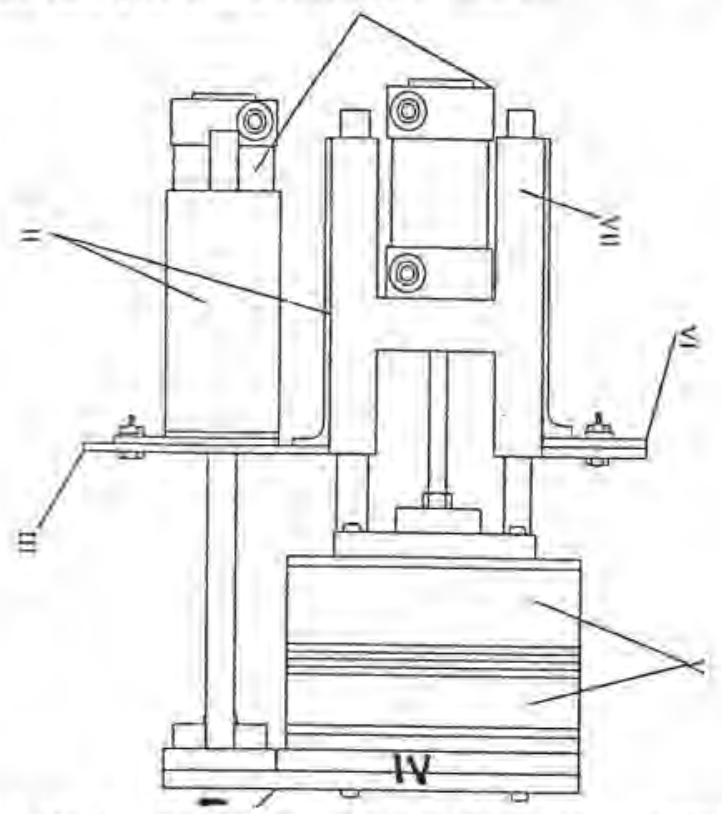

Şekil 4. Yan kaynak bölümū (I: Çift etkili silindir, Il:Kızak bağlantı flanşi IIt Makine gỏvdesi, IV:Çene bağiantı parçası, V: Çene, VI:Kaydirma Plakası, Vil:Kizak) (Duman 2000)

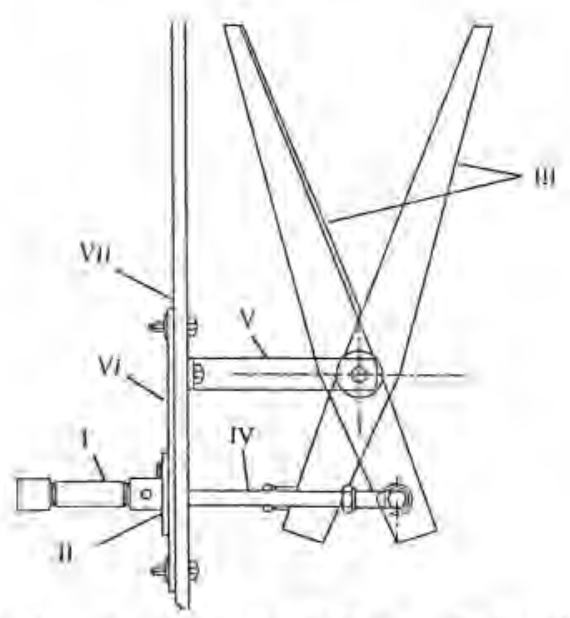

Șekil 5. Makasın yan görünùşu (l:Ciift etkili silindir, Ni:Bağlantı flanșı III:kesiciler, IV: Piston kolu uzatma parcas;, ViKesici bağlantısı, Vi:Kaydirma plakasi, VII:Makine gồvdesi) (Duman 2000) 


\section{Alt iletici}

lletioi silindir. Seçilen çî̃ etkili piston kolsuz silindirin tipi: DGPL- 8-900-PPV-A-KF-B, Piston çapl: $8 \mathrm{~mm}$, Strok: 900 $\mathrm{mm}$, Max,çalışma basıncr: 8 bar, Ozellikleri: Manyetik algilama, elastik yastiklama halkaları ile yastiklama, köçäk montaj alanında uzun strok sağlayabilirler, yüksek dönme momentlerine direnç gösterirler, rulman yatakil. Seçilen temassiz algilayicinin tipi: SME - 8-K- LED-24, lletici silindir için seçilen yön kontrol valfinin fipi. $\mathrm{MZH}-5 / 3-1,5-\mathrm{L}-$ LED, Manifold tipi: PRMZ-5-M5-2, Kablolu soket tipi:KMYZ 1- $24-2,5$, Anma debisi: $45 \mathrm{~L} / \mathrm{min}$, Basınç aralığl: 2-7 bar, Orta konum: Egzoz, Fonksiyon: $5 / 3$ selenoid kumandali, Özellikleri: 24 VDC, 0,55 W, LED ile çalisma ve emniyet göstergesi, yardımcı el kumandalı, taban plakası valî, Seçilen çift etkili ara silindirin tipi. DMML $-20-30-P-A_{i}$ Piston çapr: $20 \mathrm{~mm}$, Strok: $30 \mathrm{~mm}$, Özellikleri; Yağsız hava ille çalışabilme özellig̈i, manyetik algılama, elastik halkalar ile son konum yastıklama, değişken montaj ve dönmeyen piston kolu. Seçilen temassiz algilayıcınin tipi: SME - 8-K- LED-24. Ara silindir için kullanilan yön kontrol valfinin tipl:JMZH $-5 / 2-1,5$ L-LED, Kablolu soket tipi: KMYZ-1-24-2,5, Anma

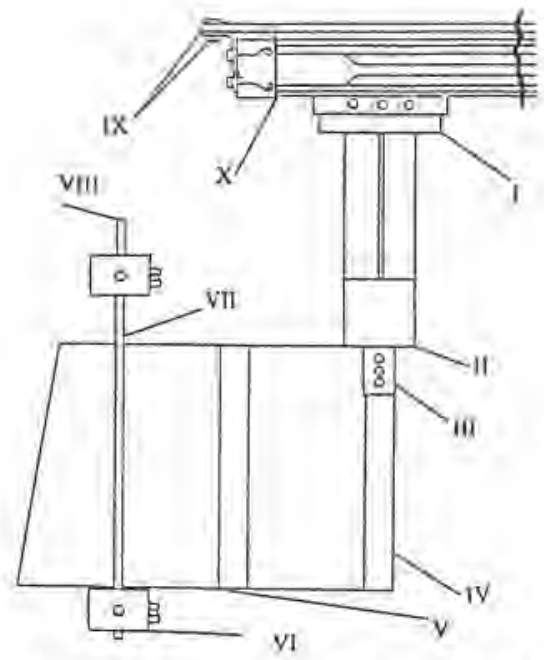

Şekil 6. Ust iletici (L: ara bağlantı parçası, III tutucu, IIItutucu parmaklan, IV:poşet, V:film, VI duzeltici çubuk adaptoro, VIl:düzeltici çubuklar, Vilt:dozeltici çubuk uç kIsmi, IX: Makine göydesi ve bağlantı vidası, $X$ çitt etkili sllindir) (Duman 2000)

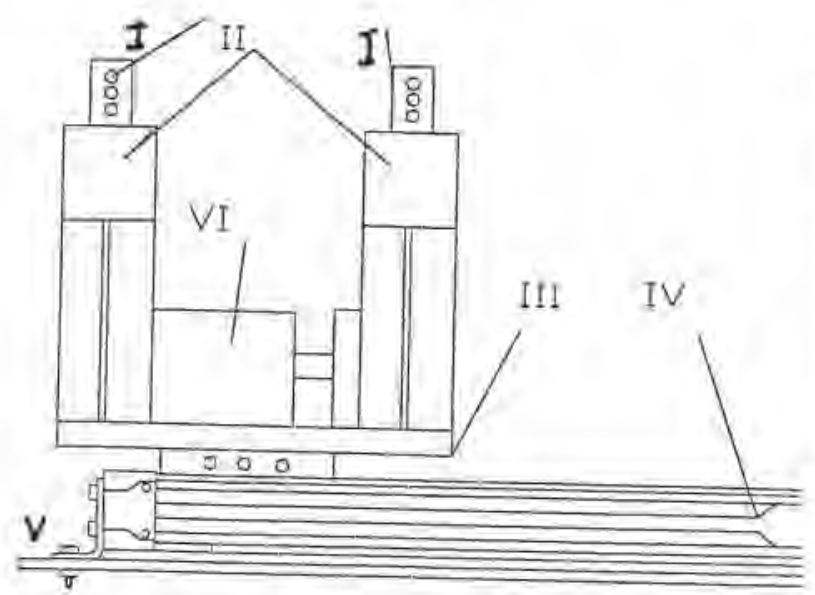

Șekil 7. Alt iletici (It.tutucu parmakdarn, II tutucular, Ill ara baǵlanil parças;, VI.çif elkili silindir, V: Makine gövdesi, VE Ara silindir) (Duman 2000) debisi: $80 \mathrm{~L} / \mathrm{min}$, Basınç aralığı: 2-7 bar, Orta konum: Cift pilotiu valf, Fonksiyon, 5/2 selenoid kumandal, Özellikleri: 24 VDC, 0,55 W. LED ile çalışma ve emniyet gostergesi,yardımci el kumandali, taban plakası valfi. Seçilen tutucunun tipi: HGP- 35-A, Piston çapl:35 mm, Yapısı: Iki parmak paralel, Tekrar hassasiyeti: $\pm 0,02 \mathrm{~mm}$, Açılma miktarı: $25 \mathrm{~mm}$, Maksimum çalışma basınci: 8 bar, Ozellikleri: Yağsız hava lie çalışabilme imkanı, manyetik algilama, yüksek tekrar hassasiyeti, sabit tutma momentleri, Seçilen temassız algilayıcinın tipi; SME - B-KLED-24. Tutucunun kontrolonde kullanilan yön kontrol valfinin tipi: JMZH - 5/2-1,5- L - LED, Kablolu soket tipi: KMYZ - 1- 24 - 2,5, Anma debisi: 80 L/min, Basınç aralığı: 2-7 bar, Fonksiyon. $5 / 3$ selenoid kumandalı, Ozellikleri: 24 VDC, 0,55 W, LED lle çalışma ve emniyet göstergesi, yardimci el kumandali, taban plakası valfi. Şekil 7'de alt iletici görölmektedir.

\section{Vakum ve uffleme}

Itme ve çekme kuvvetlerinden faydalamilacak silindirler:

Seçilen çift atkili silindirin fipi: DSNUL- 8-25 -PPV A, Piston çapl: $8 \mathrm{~mm}$. Piston kolu kenar uzunluğu: $4,5 \mathrm{~mm}$, Strok: $25 \mathrm{~mm}$, Max.çalışma basıncı: 10 bar, Özellikieri: Yağsız hava ile çalışabilme imkanı, manyetik algılama, ayarti son konum yastıklamali, alüminyum silindir kovani, haddelenmiş ve paslanmaya karşı korunmuş piston mili, donmeyen piston kolu. Seçilen temassiz algilayıcının bağlantı elamani tipí: SMBR - 16, Alglayicı tipi: SMTO4U. Cift etkili silindifler için kullanilan yön kontrol valfinin tipl: JMZH - 5/2-1,5- L - LED, Kablolu soket tipi:KMYZ 1- 24 - 2,5. Anma deblsí $80 \mathrm{~L} / \mathrm{min}$, Basınç Aralığı: 2-7 bar, Orta konum: Cilt pilotlu valf, Fonksiyon. $5 / 2$ selenoid kurriandali, Özellikleri: 24 VDC, 0,55 W, LED ile çalıșma ve emniyet göstergesi, yardimcı el kumandalı, taban plakası valfi. Vakumlama için kullanilan selenoid valfli vakum jeneratơrónôn tipi:VAD-ME-1-3/8, Basınç araliğt: 18 bar, Hava takketimi:220 L/min (6 bar'da) Özellikleri; Yardimci elle kumandali, 24 VDC ve $1,5 \mathrm{~W}$ selenoid valf lle kısa anahtarlama süresi, vakumun hizlıca yok edilmesi. Vakumlama için kullanilan vantuzların tipi: VAS- $15-1 / 8-$ PUR, Malzeme:Poliüretan, Etkin vantuz yariçapi: $12 \mathrm{~mm}$, Emme kuvveti: $7,9 \mathrm{~N}$ (0,7 bar vakum basincinda).

Ofleme grubu silindid ve diğer elemanlan: Ofleme için kullanilan yön kontrol valfinin tipi: $J M Z H-5 / 2-1,5-L-$ LED, Kablolu soket tipi:KMYZ - 1- 24-2,5, Anma debisi: $80 \mathrm{~L} / \mathrm{min}$, Basınç aralığı: $2-7$ bar, Orta konum: Çift pilotlu valf, Fonksiyon $5 / 2$ selenold kumandail, Özelilkleri: 24 VDC, $0,55 \mathrm{~W}$, LED He çalışma ve emniyet göstergesi, yardımcı el kumandalı, taban plakası valfi. Seçilen çift etkili silindirin tipi: DSNUL- 8-20-PPV-A, Piston çapi: 8 mm, Piston kolu kenar uzunluğu: $4,5 \mathrm{~mm}$, Strok: $2 \mathrm{~mm}$, Max. Çalıșma Basıncı: 10 bar, Ozellikleri: Yağsız hava ile çalışabilme imkanı, manyetik algılama, ayartı son konum yastıkłamali, alüminyum silindir kovan, haddelenmiş ve paslanmaya karșı korunmuș piston mill, dönmeyen piston kolu, Seçilen temassız algılayıcının bağlantı elemam tipi: SMBR-16, Algilayici tipl SMTO - 4U çift etkili silindir için kullanılan yön kontrol valfinin tipi: JMZH - 5/2- 1,5- L LED, Kablotu soket tipi: KMYZ - 1-24-2,5, Anma debisi: $80 \mathrm{Lmin}$, Basınç araliğil 2-7 bar, Orta konum Çift pilotlu valf, Fonksiyon. $5 / 2$ selenoid kumandalı, Özellikleri: 24 VDC, 0,55 W. LED ile çailşma ve emniyet göstergesi, yardimci el kumandali, taban plakasi valfi, Kullanilan basınç kontrol valfinin normal anma debisi: $20 \mathrm{~L} / \mathrm{min}$, Basınç aralığı: 0-9 bar, Basınç ayarı: 1-8 bar, Tip: LRMAM5-Q8-4. Şekil B'de vakum ve üfleme bolümal yer almaktadit. 


\section{Kompresör ve şartlandırıcı}

Makine üzerinde tasarımlanan bölùmlerin gerektirdiği hava debisi:

$\Sigma Q(L / m i n)=\left(Q_{1 \text { att }}+Q_{1 u \text { ust }}+Q_{2 \text { alt }}+Q_{2 \text { ust }}+\ldots+Q_{14}\right) \cdot 40+Q_{\text {vakum }}+Q_{\text {üfleme }}$

Qvakum: Vakumlama için harcanan hava miktarı (L/min). Hesaplama yapilirken, maksimum değer olan vakum jeneratörünün hava tüketimi dikkate alınmıştır Qufleme: Üfleme için harcanan hava miktarı (L/min).

Hesaplama yapilırken, maksimum değer olan ufleyici yön kontrol valfinin debisi dikkate alınmıștır.

$\Sigma Q=22+22+14+14+57,2+58+58+1,88+1,88+12+5,6+10,8+$

$11,2+2,4+0,44+0,44+0,32+220+80=534,16 \mathrm{~L} / \mathrm{min}$

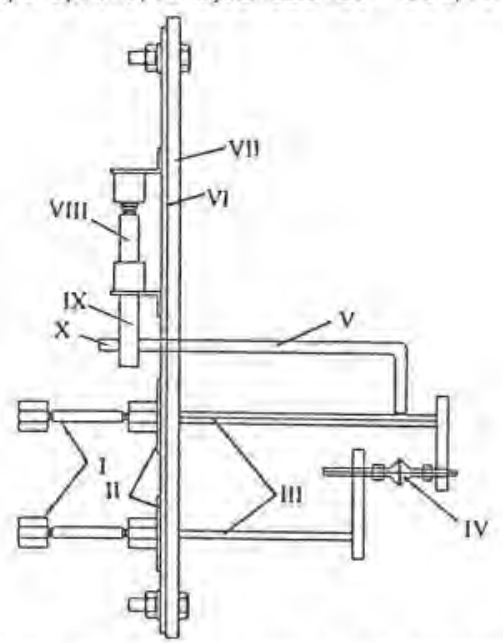

Şekil 8. Vakum ve üfleme bölümü (l:Vakumlama Silindiri II:Bağlantı flanşı, III:Piston kolu uzatma parçası, IV:PU vantuz, V:Ofleme borusu, VI:Kaydirma plakası, VII: Makine gövdesi, Vill:Ûfleme silindiri, IX:Öfleme borusu tutucusu, $X$ :Ofleme borusu hortum bağlantı ucu) (Duman 2000)
Kompresör, makine uzerinde tasarımlanan bölümler için 534,16 L/min debiyi sağlamak durumundadir. Şartlandırıcı ise gerekli debideki havanın filtre edilmesi ve istenilen sistem basıncının sabit kontrolünù sağlamalıdır. Kompresörün nihai seçiminde hava dağıtım sisteminin kayıpları da eklenecektir. Kompresör tipi olarak, genelde gıda ve ilaç endüstrisinde kullanılan, diyaframi pistonlu kompresör uygundur. Bunun yanında tasarım yapılırken hortum çapları $8.1,25 \mathrm{~mm}$ ve $4.0,75 \mathrm{~mm}$ alınmıştır.

\section{PLC program!}

Makine üzerindeki elektropnömatik ekipmanlanın çalışma sırası STL (Statement Lıst) dilinde hazırlanmış olan PLC programı ile kontrol edilmektedir. Çizelge 2. de makine elemanlarının hareketlerinin akış programı verilmiştir.

Çizelge üzerinde yer alan simgelerin anlamları:
A: Açık
K: Kapalı
1: lleri
G:Geri

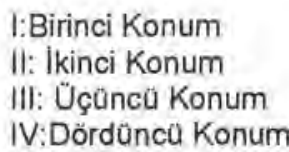

Yıldızlı simgeler, 0 andaki değişen hareket anlamını almaktadir.

Öneğin: 6, konumda; çeneler kapanıyor, üst iletici piston kolsuz silindiri I. Konumuna dönôyor, tutucu açiliyor. Hareketler PLC'ye algilama sensörlerinden gelen sinyaller ile bildirilmektedir. PLC'ye gelen sinyalleri değerlendirerek selenoid bobinlere sinyaller göndermektedir. PLC'nin göndermiş olduğu sinyaller $1 \varnothing$ (Input) olarak adlandinimaktadir. PLC, gelen sinyalleri değerlendirerek selenoid bobinlere sinyaller göndermektedir. PLC'nin göndermiş olduğu sinyaller $O \varnothing$ (output) olarak adlandırimaktadır.

Çizelge 2. Hareket akış programı

\begin{tabular}{|c|c|c|c|c|c|c|c|c|c|c|c|c|c|}
\hline & \multirow{2}{*}{$\begin{array}{c}\text { Alt } \\
\text { çene }\end{array}$} & \multirow{2}{*}{$\begin{array}{l}\text { Yan } \\
\text { çene }\end{array}$} & \multicolumn{2}{|c|}{ Ust iletici } & \multirow{2}{*}{ Makas } & \multicolumn{3}{|c|}{ Alt iletici } & \multicolumn{2}{|c|}{ Vakum } & \multicolumn{2}{|c|}{ Üfleme } & \multirow{2}{*}{ Ust çene } \\
\hline & & & Silindir & Tutucu & & Silindir & Tutucu & $\begin{array}{c}\text { Ara } \\
\text { silindir }\end{array}$ & Vakum & Silindir & Silindir & Ofleme & \\
\hline 1. & A & A & I. & $\mathrm{A}$ & A & 1. & $A$ & I & $\mathrm{K}$ & $G$ & G & $\mathrm{K}$ & A \\
\hline 2. & A & A & 1 & $\mathrm{~K}^{*}$ & A & I. & A & I & $K$ & G & G & $K$ & A \\
\hline 3. & A & A & $11^{*}$ & $\mathrm{~K}$ & A & I. & A & i & $\mathrm{K}$ & G & G & $\mathrm{K}$ & A \\
\hline 4. & A & A & II. & $\mathrm{K}$ & $\mathrm{K}^{*}$ & I. & A & i & $\mathrm{K}$ & G & G & $\mathrm{K}$ & A \\
\hline 5. & A & A & II. & $\mathrm{K}$ & $A^{*}$ & 1. & A & i & $K$ & $G$ & G & $K$ & A \\
\hline 6. & $K^{*}$ & $\mathrm{~K}^{*}$ & $1 .^{*}$ & $A^{*}$ & A & I. & A & i & $K$ & G & G & $\mathrm{K}$ & $\mathrm{K}^{*}$ \\
\hline 7. & $A^{*}$ & $A^{*}$ & 1. & $K^{*}$ & $A$ & I. & A & i & $k$ & G & $\mathrm{G}$ & $\mathrm{K}$ & $A^{*}$ \\
\hline 8. & A & A & $11 .^{*}$ & $K$ & A & 1. & A & i & $K$ & G & G & $K$ & A \\
\hline 9. & A & A & II. & $\mathrm{K}$ & $\mathrm{K}^{*}$ & I. & A & i & $\mathrm{K}$ & $G$ & G & $\mathrm{K}$ & A \\
\hline 10. & A & A & II. & $K$ & $A^{*}$ & 1. & A & i & $\mathrm{K}$ & G & G & $\mathrm{K}$ & A \\
\hline 11. & A & A & III. ${ }^{*}$ & $\mathrm{~K}$ & A & I. & A & I & $\mathrm{K}$ & G & $\mathrm{G}$ & $K$ & A \\
\hline 12. & A & $A$ & III. & $A^{*}$ & A & 1. & A & 1 & $\mathrm{~K}$ & G & G & $\mathrm{K}$ & A \\
\hline 13. & A & A & III. & A & A & 1. & $\mathrm{~K}^{*}$ & i & $K$ & G & G & $\mathrm{K}$ & A \\
\hline 14. & $\mathrm{~K}^{*}$ & $\mathrm{~K}^{*}$ & $1^{*}$ & A & A & 11.* & $\mathrm{K}$ & $\mathrm{G}^{*}$ & K & $i^{*}$ & $i^{*}$ & $\mathrm{~K}$ & $\mathrm{~K}^{*}$ \\
\hline 15. & $\mathrm{~A}^{+}$ & $A^{*}$ & 1. & $\mathrm{~K}^{*}$ & A & II. & $\mathrm{K}$ & $\mathrm{G}$ & $A^{*}$ & 1 & 1 & $A^{*}$ & $A^{\prime \prime}$ \\
\hline 16 & A & A & $11 .^{*}$ & $\mathrm{~K}$ & $\bar{A}$ & II & $K$ & G & $\mathrm{K}^{*}$ & $\mathrm{G}^{*}$ & $G^{*}$ & $\mathrm{~K}^{*}$ & A \\
\hline 17. & A & A & II. & $\mathrm{K}$ & $\mathrm{K}^{*}$ & III.* & $\mathrm{K}$ & $\mathrm{G}$ & $\mathrm{K}$ & G & G & K & $A$ \\
\hline 18. & A & A & II. & $\mathrm{K}$ & $A^{*}$ & III. & $\mathrm{K}$ & G & $K$ & $G$ & G & $\mathrm{K}$ & $\mathrm{A}$ \\
\hline 19. & A & A & III. ${ }^{*}$ & $K$ & A & III. & $K$ & G & $K$ & G & $\mathrm{G}$ & $K$ & $A$ \\
\hline 20. & A & A & III & $\mathrm{K}$ & $A$ & $\mathrm{IV}^{*}$ & $\mathrm{~K}$ & $1 *$ & $K$ & G & $G$ & $\mathrm{~K}$ & A \\
\hline 21. & A & $A$ & III & $\mathrm{K}$ & $A$ & IV. & $\mathrm{A}^{*}$ & 1 & $\mathrm{~K}$ & $G$ & G & $\mathrm{K}$ & A \\
\hline 22. & $\mathrm{~K}^{*}$ & $K^{*}$ & III. & $\mathrm{K}$ & A & $i^{*}$ & A & 1 & $K$ & G & $\mathrm{G}$ & $K$ & $K^{*}$ \\
\hline
\end{tabular}




\section{Kaynaklar}

Anonim, 1991. Pnömatik Elektronik Tips. Festo KG, 35 s., Esslingen.

Anonim, 1994a. Temel Pnömatik. Çev: Sait Sipahioğlu, Evren Ofset A.Ş. Web ofset tesisleri, MEB Yayınları $182 \mathrm{~s}$, Ankara.

Anonim, 1994b. Pnömatik Arıza Arama Becerisini Geliştirme Çev:Sait Sipahioğlu, Evren Ofset A.Ş. Web ofset tesisleri, MEB Yayınları, $166 \mathrm{~s}$, Ankara.

Anonim, 1994c. Pnömatik. Çev:Yaşar Pancar, Etem A.Ş. Matbaa Tesisleri. MEB Yayınları, 196 s, Eskişehir.

Anonim,1998. Horizontal Packing Machine Technical Notes. HM Corp., Spain.

Briston J. H. 1980. Rigid Plastic Packaging. In: S.J. Palling (ed.), Developments in Food Packagaing, Vol. 1. Applied Science, pp. 27-53., London.

Croser, P. 1990. Festo Didaktik Temel Seviye TP 101 Öğretim Kitabı Çev: F. Çevik. Festo Didactic KG, 226 s., Esslingen.

Duman, G. 2000. Paketleme Makinasında Selofan Kaynak Yapma Mekanizmasının Pnömatik Kontrolü. Ankara Üniv. Fen Bil.Enst. Tarım Makinelerı ABD, Yüksek Lisans Tezi, $111 \mathrm{~s}$, Ankara.

Erdoğan, D. 1984. Makine Malzeme Bilgisi. A.Ü. Ziraat Fakültesi Yayınları: 913, 1-223, Ankara.

Fellows, P. J. 1992. Food Processing Technology Principles and Practice. Ellis Horwoord Limited, pp. 421 - 461, England.
Graham, F. D. 1957. Audels Pumps - Hydraulics - Air Compressors. The Audel and CO., pp: 1- 406, New York.

Guise, B. 1987. Filling an Industry Need. Food Proces, July 31 33.

Hemeon, W. C. L. 1995: Plant and Process Ventilation. The Industrial Press. pp: 265- 302, New York.

Hersom, A. C. and E. D. Hulland, 1980. Canned Foods. $7^{\text {th }}$ edn., Churchill Livingstone. pp. 67-102, $342-356$., London.

Karacan, I. 1994. Pnömatik Kontrol. Özışık Matbaacılık, 304 s, Ankara.

Malin, J. D. 1980. Metal Containers and Closures. In: S.J. Palling (ed.), Developments in food packaging, Vol. 1. Applied Science. pp. 1 - 26., London.

Peurifoy, R. L. 1956. Construction Planning, Equipment And Methods. Mc Graw - Hill Book Company, Inc., pp: 217 236, New York.

Pippenger, J. J. and R. M. Koff. 1956. Fluid - Power Controls. Me Graw - Hill Book Company, Inc., pp: 1-246, New York.

Stepanoff, A. J. 1955. Turboflowers. John Wiley and Sons Inc., pp: 1 - 369, New York.

Stewart, H. L. and F. D. Jefferis. 1955. Hydraulic And Pneumatic Power For Production. Machinery Publishing Co., New York. 